\title{
Expression analysis of peptide growth factors VEGF, FGF2, TGFB1, EGF and IGF1 in prostate cancer and benign prostatic hyperplasia
}

\author{
NIKOLAOS SOULITZIS ${ }^{1}$, IOANNIS KARYOTIS ${ }^{2}$, DEMETRIOS DELAKAS $^{2}$ and DEMETRIOS A. SPANDIDOS ${ }^{1}$ \\ ${ }^{1}$ Laboratory of Clinical Virology, Medical School, University of Crete; ${ }^{2}$ Department of Urology, \\ University Hospital of Heraklion, Heraklion, Crete, Greece
}

Received January 5, 2006; Accepted February 7, 2006

\begin{abstract}
Peptide growth factors play an important role in several intracellular processes, such as cellular growth and differentiation, angiogenesis and apoptosis, as well as in carcinogenesis, since they contribute significantly to the malignant transformation. The prostate gland is abundant in growth factors. The two most known prostatic diseases, prostate cancer $(\mathrm{PCa})$ and benign prostatic hyperplasia $(\mathrm{BPH})$, are among the most common diseases that affect elderly men. This study was conducted using a quantitative real-time RTPCR method in order to determine mRNA expression levels of peptide growth factors VEGF, FGF2, TGFB1, EGF, and IGF1 in tissue specimens from 42 patients with PCa, 42 with $\mathrm{BPH}$, and 10 normal prostate samples obtained post-mortem from young individuals, in order to examine their association with prostatic hyperplasia and neoplasia. Our results show that in PCa, growth factors VEGF, EGF and FGF2 are overexpressed, while TGFB1 and IGF1 have reduced mRNA levels. In BPH, transcript levels of FGF2 and EGF are normal, while VEGF, TGFB1 and IGF1 exhibit downregulation. Further statistical analysis revealed that $\mathrm{PCa}$ patients with high levels of PSA blood levels have decreased FGF2 expression $(\mathrm{p}=0.016)$. Additionally, cancer patients with low Gleason score $(<7)$ have increased EGF $(\mathrm{p}=0.035)$ and IGF1 $(\mathrm{p}=0.031)$ mRNA levels. IGF1 levels are also elevated in tumors with TNM stages T1-T2 ( $\mathrm{p}=0.030)$. In $\mathrm{BPH}$, older patients have reduced EGF expression ( $p=0.018$ ), while IGF1 is overexpressed in younger patients ( $\mathrm{p}=0.041)$. Additionally, the coexpression pattern of the five studied growth factors differs significantly among normal, benign and malignant prostate. These results implicate VEGF, FGF2, TGFB1, EGF and IGF1
\end{abstract}

Correspondence to: Professor Demetrios A. Spandidos, Laboratory of Clinical Virology, Medical School, University of Crete, P.O. Box 2208, Heraklion 71003, Crete, Greece

E-mail: spandidos@spandidos.gr

Key words: mRNA, real-time PCR, SYBR ${ }^{\circledR}$ Green I, cell-cycle, angiogenesis in the development of both $\mathrm{PCa}$ and $\mathrm{BPH}$, rendering them potential targets for disease detection, monitoring and therapy.

\section{Introduction}

Prostate cancer ( $\mathrm{PCa}$ ) is the most common malignancy in the Western world, accounting for more than 230,000 new cases and 30,000 cancer-related deaths per year in the US alone (1). Although prostate cancer can be treated, when diagnosed at an early stage, patients with advanced or metastatic disease have 5-year survival rates less than $35 \%$ (1). Diets rich in animal fats and red meat and poor in fruits and vegetables have been associated with increased risk of prostate cancer (2). Moreover, several genetic events, such as androgen receptor polymorphisms (3), c-myc overexpression or PTEN inactivation (4), have been implicated in prostate carcinogenesis. Identification of genetic markers for early disease detection could lead to improved treatment strategies, prolonging the survival of patients with prostatic neoplasia.

Benign prostatic hyperplasia (BPH), a hypertrophy of the prostate gland that leads to the obstruction of urinary flow, has a severe negative impact on the quality of life in elderly men, since it affects more than $70 \%$ of men aged above 70 (5). More than $40 \%$ of BPH cases harbor inflammatory sites, mainly sites with chronic prostatitis (6), while it has also been suggested that BPH could be the precursor of some cases of prostatic neoplasia, especially those developing in the transition zone of the prostate (7). Various intracellular alterations, such as reduced expression of steroid hormone receptors, increased angiogenesis and decreased apoptosis, have been observed in $\mathrm{BPH}$ (8), shedding new light on the mechanisms of $\mathrm{BPH}$ development and progression.

Peptide growth factors are proteins that regulate cellular growth, differentiation and programmed cell death (apoptosis). Several oncogenes that are involved in the malignant transformation of a cell are growth factors of growth factor receptors. Growth factors use autocrine or paracrine pathways to signal stromal and epithelial cells in the microenvironment. Growth factors play a significant role in the regulation and growth of normal, hyperplastic and malignant prostatic epithelium. The most important ones are: the epidermal growth factor (EGF) family, the fibroblast growth factor (FGF) family, the insulin-like growth factor (IGF) family, the trans- 
forming growth factor-beta (TGFB) family, and the vascular endothelial growth factor (VEGF) family $(9,10)$.

The two most common members of the EGF family are EGF and TGFA. These polypeptides have $35 \%$ sequence homology and similar structure, which explains the small differences in their ability to bind and regulate their common receptor the EGFR, a $170 \mathrm{kDa}$ transmembrane protein with tyrosine kinase function $(11,12)$. EGF promotes cell proliferation and is involved in embryogenesis, angiogenesis and cellular differentiation (12). The normal prostatic epithelium produces large amounts of EGF (13), a function which is regulated by androgens. In benign and malignant prostate, overexpression of EGF protein has been observed. However, these findings are not consistent $(14,15)$.

The FGF family of growth factors contains several members, including basic FGF (bFGF or FGF2), acidic FGF (aFGF or FGF1) and keratinocyte growth factor (KGF or FGF7), that have 30-55\% amino-acid homology and are expressed in varying levels by prostatic cells (16). FGFs are mitogenic for various cell types, regulate extracellular matrix remodeling and promote angiogenesis, especially in tumors (16-18). FGF2, a 146 amino-acid polypeptide (16), is abundant in the normal prostate, regulating mesenchymal homeostasis (19). It is primarily produced by prostatic fibroblasts and its expression is regulated by androgens (20). FGF2 has also been implicated in the development of BPH, since its mRNA is overexpressed, a finding that correlates with increased stromal proliferation (21-23). However, its role in the malignant transformation of the prostate has not been elucidated yet, but it appears that the development of an autocrine FGF2 pathway contributes significantly to the progression of prostatic malignancy to androgen independence. Moreover, its role is significant in tumor angiogenesis, stimulating endothelial cells, and in tumor metastasis, through the remodeling of the extracellular matrix $(16,24)$.

TGF-beta family contains five isoforms, TGFB1-B5, of which only TGFB1-B3 are expressed in mammals (25). The mature polypeptides have 112 amino-acids, share $80 \%$ sequence homology and have similar biological activities (26-29). TGFB is secreted as an inactive larger polypeptide precursor, which, after processing, gives the active mature $25 \mathrm{kDa}$ polypeptide dimer (30). TGFB is found in a variety of tissues. Its role is complex, since it can act both as a stimulator or inhibitor of cellular growth, depending on cell type and the state of cellular differentiation (29). TGFB is important in embryogenesis, stimulates angiogenesis in wound healing (31), promotes extracellular matrix formation (32) and suppresses the immune system $(29,33-35)$. Its effects are mediated by its receptors, TGFBRs, of which TGFBR1-3 are found in mammals (36). TGFB has mainly an inhibitory role in the normal prostate, as well as in BPH (37), controlling proliferation and inducing apoptosis in epithelial cells (3841). In prostatic neoplasia, TGFB levels increase $(42,43)$, a finding that is associated with tumor development and progression $(43,44)$, because the diverse biological activities of TGFB are exploited by cancer cells. Since TGFB promotes angiogenesis (45), it allows new vessels to bring nutrients and oxygen to tumor cells. Additionally, as a potent immunosuppressor $(29,34,35)$, it protects cancer cells from the host immune system (46). Finally, through its role in extracellular matrix formation, it enhances the invasiveness and metastatic ability of malignant cells (47-49).

VEGF, a homologue of platelet-derived growth factor (PDGF), often referred to as VEGFA, is a $45 \mathrm{kDa}$ heparinbinding homodimeric glycoprotein. Alternative exon splicing produces four major VEGF isoforms, $\mathrm{VEGF}_{121}, \mathrm{VEGF}_{165}$, $\mathrm{VEGF}_{189}$ and $\mathrm{VEGF}_{209}$, and four less frequent ones. The primary role of VEGF is neovascularization, the stimulation of endothelial cells to form new blood vessels, a function which is mediated by two tyrosine kinase receptors, VEGFR1 and VEGFR2 (50). VEGF is mainly stimulated by hypoxic conditions (51), but many other growth factors, and especially FGF2, can lead to its upregulation (50). VEGF is often called vascular permeability factor, since it enhances vascular leakage, an effect that contributes significantly to tumor development and metastasis (52). VEGF has been observed in BPH stromal cells (53), as well as in prostate cancer epithelial cells $(53,54)$, where it plays a significant role in tumor growth, inducing angiogenesis. This function, however, is regulated by androgens, since androgen deprivation leads to decreased VEGF expression and to destabilization of VEGF mRNA transcripts (55).

The IGF family comprises primarily two members, IGF1 and IGF2, single-chain polypeptides that are structurally and functionally similar to insulin (56-58). They are a part of a greater protein network that also includes 2 receptors (IGF1R and IGF2R) and 6 binding proteins (IGFBPs) (59). Both factors are produced in many human tissues, primarily by stromal cells and stimulate epithelial cell proliferation by paracrine action. Production of IGF1 by epithelial cells is one of the changes that accompanies prostate adenocarcinoma development (60). Moreover, high IGF1 blood levels have been associated with prostatic malignancy $(61,62)$, but not with BPH (63). It also appears that IGF1 contributes to prostate cancer progression after castration and estrogen therapy.

The purpose of this study was to examine mRNA expression of peptide growth factors EGF, FGF2, TGFB1, VEGF and IGF1, in both benign and malignant prostatic tissues, in order to find any differences from the observed expression in the normal prostatic epithelium, and to determine whether their co-expression pattern is altered or disrupted in benign prostatic hyperplasia or prostate cancer.

\section{Materials and methods}

Study populations. Tissue specimens, from 42 patients with prostate cancer who underwent radical prostatectomy and from 42 patients with benign prostatic hyperplasia who underwent suprapubic or transurethral resection, were collected within a 3.5-year period (from May 2000 to November 2003) at the Department of Urology, University Hospital of Heraklion, Crete, Greece. Median age at diagnosis was 68.5 years (range 54-82) for PCa subjects and 72.5 years (range 57-86) for BPH patients. Prostate specific antigen (PSA) blood levels were measured for all patients. Prostate carcinomas stage (TNM) and grade (Gleason score), as well as the presence of inflammation (prostatitis) in BPH subjects, was determined by histological examination using hematoxylin and eosin-stained slides. Since the prostate gland is not normal in old individuals, we used 
Table I. Clinicopathological characteristics of the study groups.

\begin{tabular}{|c|c|c|c|}
\hline & $\begin{array}{c}\text { Prostate } \\
\text { cancer }(\%)\end{array}$ & $\begin{array}{l}\text { Benign prostatic } \\
\text { hyperplasia }(\%)\end{array}$ & $\begin{array}{l}\text { Normal } \\
\text { controls }\end{array}$ \\
\hline Cases, $\mathrm{n}$ & 42 & 42 & 10 \\
\hline $\begin{array}{l}\text { Age } \\
(\text { mean } \pm \mathrm{SD}, \text { years })\end{array}$ & $68.1 \pm 6.2$ & $71.8 \pm 7.7$ & $24.8 \pm 2.7$ \\
\hline $\begin{array}{l}\text { PSA blood levels } \\
(\text { mean } \pm \mathrm{SD}, \mathrm{ng} / \mathrm{ml})\end{array}$ & $13.0 \pm 12.3$ & $2.2 \pm 1.7$ & - \\
\hline \multicolumn{4}{|l|}{ TNM } \\
\hline T1-T2 & $20(47.6)$ & - & - \\
\hline T3-T4 & $22(52.4)$ & - & - \\
\hline \multicolumn{4}{|l|}{ Gleason score } \\
\hline $2-6$ & $25(59.5)$ & - & - \\
\hline $7-10$ & $17(40.5)$ & - & - \\
\hline \multicolumn{4}{|l|}{ Inflammation } \\
\hline Yes & - & $19(45.2)$ & - \\
\hline No & - & $23(54.8)$ & - \\
\hline
\end{tabular}

specimens from 10 young subjects (aged 20-28) as a source of normal prostatic tissue. Specimens were collected postmortem, within $8 \mathrm{~h}$ of the time of death, at the same hospital. All normal, benign and malignant samples were immediately frozen after surgical removal and stored at $-80^{\circ} \mathrm{C}$ until used. The clinical and histopathological characteristics of all samples are listed in Table I. The ethics committees of the University of Crete and the University Hospital of Heraklion approved this study and written informed consent was obtained from all participants or their relatives.

RNA extraction and cDNA preparation. Tissue specimens were homogenized in the TRIzol ${ }^{\circledR}$ reagent (Invitrogen, Carlsband, CA) using a power homogenizer and incubated at room temperature, followed by chloroform addition and centrifugation. Total RNA was precipitated from the supernatant with isopropanol, washed with $75 \%$ ethanol and resuspended in $50 \mu 1$ DEPC-treated water. RNA concentration and purity was calculated after measuring on a UV spectrophotometer its $260 \mathrm{~nm}$ absorbance and 260/280 $\mathrm{nm}$ absorbance ratio respectively.

cDNA was synthesized by reverse transcription (RT) with the Thermoscript ${ }^{\mathrm{TM}}$ RT kit (Invitrogen), using random hexamers as amplification primers. In detail, $2.5 \mu \mathrm{g}$ of total RNA, $50 \mathrm{ng}$ of random hexamers and $1 \mathrm{mM}$ dNTPs were heated at $65^{\circ} \mathrm{C}$ for $5 \mathrm{~min}$, in order to remove RNA secondary structures, and placed on ice until the addition of cDNA synthesis mix, which contains $1 \mathrm{X}$ cDNA synthesis buffer (50 mM Tris-acetate $\mathrm{pH} 8.4,75 \mathrm{mM}$ potassium acetate, $8 \mathrm{mM}$ magnesium acetate), $5 \mathrm{mM}$ dithiothreitol (DTT), $40 \mathrm{U}$ RNaseOut $^{\mathrm{TM}}$ and $15 \mathrm{U}^{\text {Thermoscript }}{ }^{\mathrm{TM}}$ reverse transcriptase. The final mix (volume $20 \mu \mathrm{l}$ ) was incubated for $10 \mathrm{~min}$ at
Table II. Primer sequences used for quantitative real-time RT-PCR.

\begin{tabular}{lcc}
\hline $\begin{array}{l}\text { Primer } \\
\text { pair }\end{array}$ & Sequence (5'-3') & $\begin{array}{c}\text { Amplicon } \\
\text { size (bp) }\end{array}$ \\
\hline EGF & $\begin{array}{l}\text { CTTGTCATGCTGCTCCTCCTG } \\
\text { TGCGACTCCTCACATCTCTGC }\end{array}$ & 118
\end{tabular}

FGF2 CTGGCTATGAAGgAagATGGA 149

TGFB1 AAGGACCTCGGCTGGAAGTG

VEGF ATGACGAGGGCCTGGAGTGTG CCTATGTGCTGGCCTTGGTGAG

IGF1 CCTCCTCGCATCTCTTCTACCTG
CTGCTGGAGCCATACCCTGTG 166 $\begin{array}{ll}\text { GAPDH } & \text { GGAAGGTGAAGGTCGGAGTCA } \\ \text { GTCATTGATGGCAACAATATCCACT }\end{array}$ $25^{\circ} \mathrm{C}$ for primer extension, and cDNA synthesis was conducted at $55^{\circ} \mathrm{C}$ for $50 \mathrm{~min}$. The reaction was terminated by heating at $85^{\circ} \mathrm{C}$ for $5 \mathrm{~min}$. In order to remove the RNA template, cDNA was incubated at $37^{\circ} \mathrm{C}$ for 20 min with $2 \mathrm{U}$ of $E$. coli $\mathrm{RNaseH}$, and stored at $-20^{\circ} \mathrm{C}$ until used.

Real-time reverse transcriptase-polymerase chain reaction assay. Peptide growth factors mRNA expression was measured using a real-time RT-PCR assay with SYBR ${ }^{\circledR}$ Green I. Glyceraldehyde-3-phosphate dehydrogenase (GAPDH) was used as internal control, in order to normalize EGF, FGF2, TGFB1, VEGF and IGF1 mRNA expression levels. The mRNA-specific primers used are listed in Table II. After initial experiments, in order to optimize $\mathrm{Mg}^{2+}$, along with primers' concentration and annealing temperature, $1 \mu \mathrm{l}$ cDNA from normal, benign or malignant prostate samples was amplified in a PCR reaction containing 2X Brilliant SYBR ${ }^{\circledR}$ Green QPCR Master Mix (containing $2.5 \mathrm{mM} \mathrm{MgCl}$ ), $300 \mathrm{nM}$ of each primer and $30 \mu \mathrm{M}$ Rox passive reference dye, in a final volume of $20 \mu 1$. To ensure the accuracy of quantification measurements, a representative pool of all samples was diluted in a series of five $2 \mathrm{X}$ dilutions, and was run in the same plate, in order to construct a standard curve for the quantification process. After initial denaturation at $95^{\circ} \mathrm{C}$ for $10 \mathrm{~min}$, samples were subjected to 45 cycles of amplification, comprised of denaturation at $95^{\circ} \mathrm{C}$ for $30 \mathrm{sec}$, annealing at $60^{\circ} \mathrm{C}$ for $30 \mathrm{sec}$ and elongation at $72^{\circ} \mathrm{C}$ for $30 \mathrm{sec}$, followed by a melt curve analysis, in which the temperature was increased from $55^{\circ} \mathrm{C}$ to $95^{\circ} \mathrm{C}$ at a linear rate of $0.2^{\circ} \mathrm{C} / \mathrm{sec}$. Data collection was performed both during annealing and extension, with two measurements at each step, and at all times during melt curve analysis. All PCR experiments were conducted on Mx3000P real-time PCR 

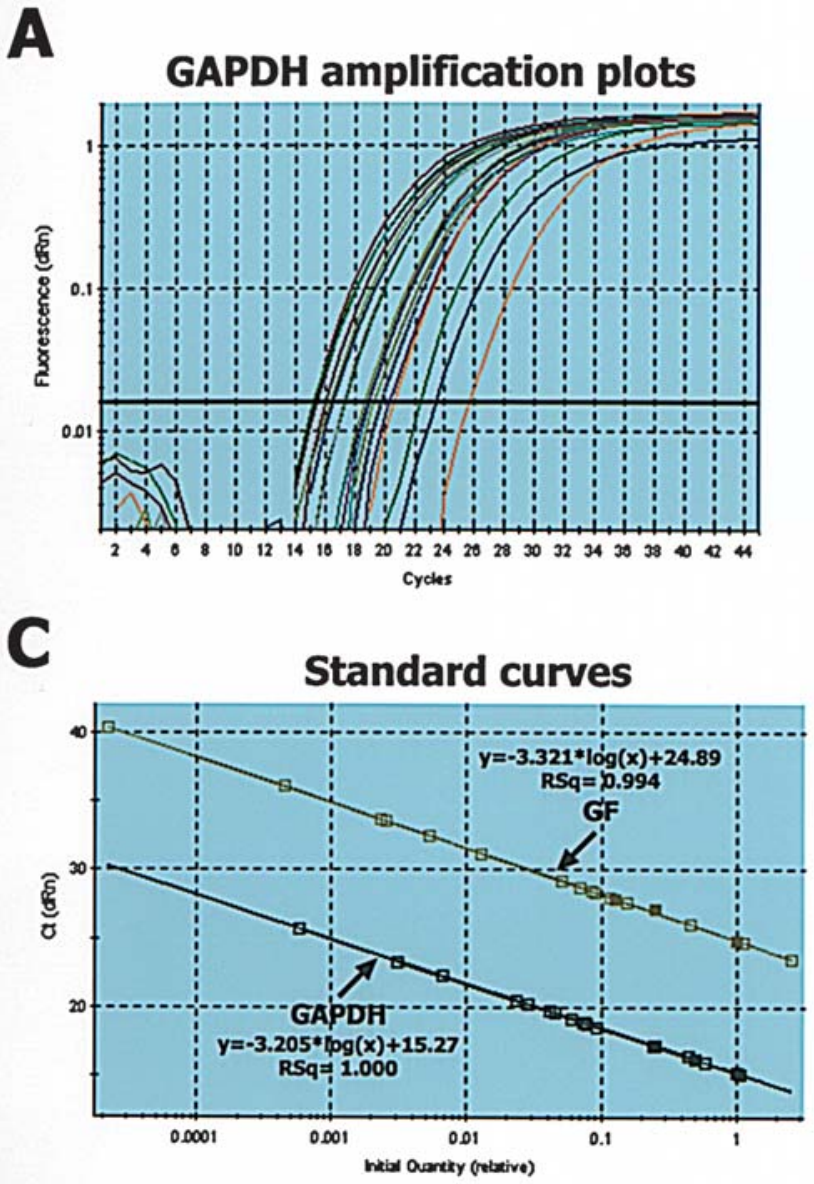

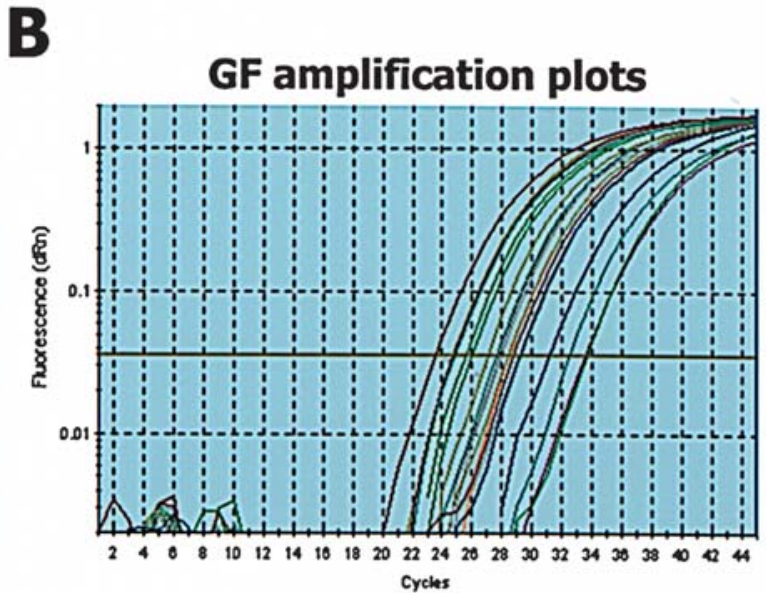

D

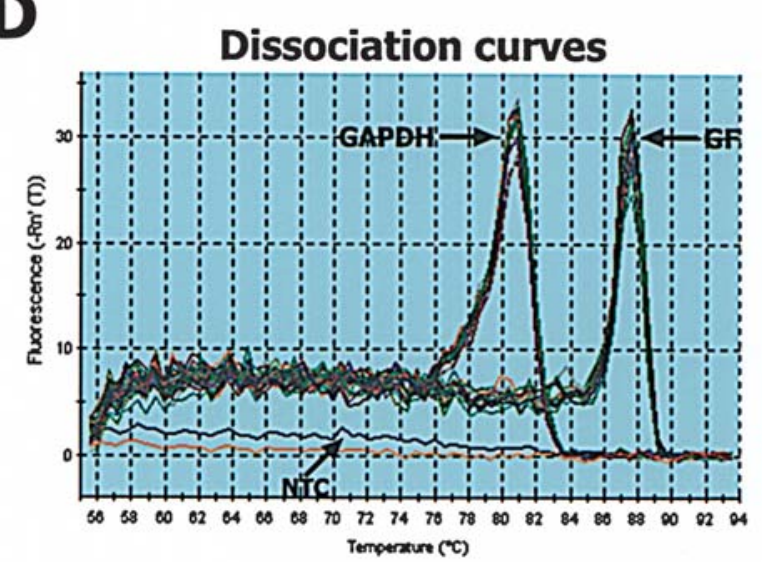

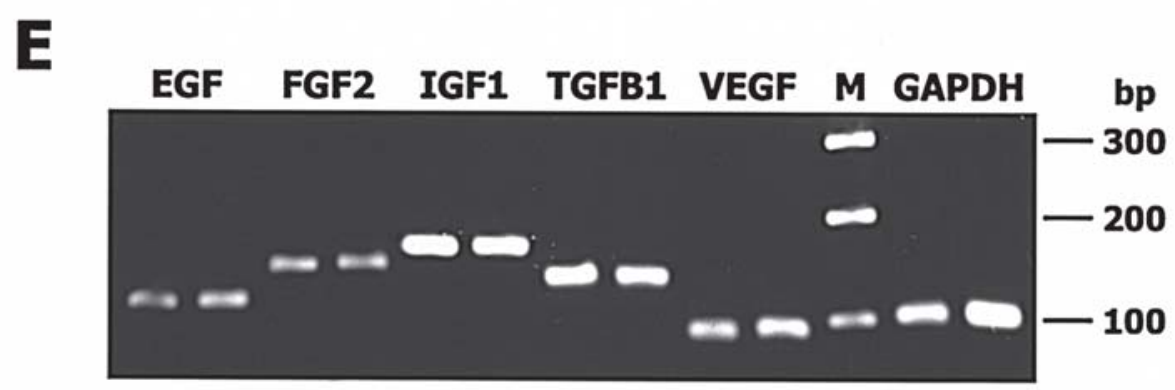

Figure 1. Representative examples of real-time quantitative PCR using SYBR Green I detection dye. (A), Amplification plots of internal control (GAPDH). (B), Amplification plots of target gene (growth factor, GF). (C), Standard curves for both target (GF) and control (GAPDH) genes. (D), Dissociation curves of target gene (GF) and internal control (GAPDH). NTC, non-template control. (E), Representative examples of PCR products, after analysis in a $2 \%$ agarose gel, from the five studied growth factors (EGF, FGF2, IGF1, TGFB1 and VEGF). GAPDH, internal control. M, 100-bp DNA ladder.

thermal cycler using the software version 2.00, Build 215 Schema 60 (Stratagene, La Jolla, CA). To verify the results of the melt curve analysis, PCR products were analyzed by electrophoresis in $2 \%$ agarose gels, stained with ethidium bromide and photographed on a UV light transilluminator. PCR products length, for all growth factors analyzed, as well as for GAPDH, are stated in Table II. In each PCR reaction two negative controls were included, one with no cDNA template and one with no reverse transcription treatment. Peptide growth factor transcription levels were calculated using the following formula: Normalized Sample/Control = $\left(1+\mathrm{E}_{\mathrm{GF}}\right)^{-\mathrm{ACt}} \mathrm{GF} /\left(1+\mathrm{E}_{\mathrm{GAPDH}}\right)^{-\Delta \mathrm{Ct}} \mathrm{GAPDH}_{\text {. }}$ 2-fold increased or decreased expression was considered significant. Procedures were repeated with cDNA template synthesized 3 times from the same RNA. Each sample's mRNA levels, for every growth factor tested, represent the mean value of data acquired from three independent RT-PCR experiments.

Statistical analysis. Peptide growth factor mRNA levels were first evaluated by one-sample Kolmogorov-Smirnov goodness of fit test, in order to determine whether they follow a normal distribution pattern. Depending on the results, Pearson's correlation or the non-parametric Spearman rank correlation was used to examine their relation pair-wise and their association with continuous variables (Age, PSA levels). Moreover, their association with categorical data (TNM, Gleason score, inflammation) was examined using Student's t-test (after examining for equality of variances with Levene's test), or its non-parametric equivalents Mann-Whitney $U$ and Kruskal-Wallis $\mathrm{H}$ tests. Finally, the Chi-square $\left(\chi^{2}\right)$ test, using 


\section{Prostate Cancer}

\begin{tabular}{|c|c|c|c|c|c|c|c|c|c|}
\hline No & Age & TNM & GI & PSA & VEGF & FGF2 & TGFB1 & EGF & IGF1 \\
\hline $1 \mathrm{Ca}$ & 70 & T2b & 8 & 12.7 & & & & & \\
\hline $2 \mathrm{Ca}$ & 73 & T3a & 7 & 30.0 & & & & & \\
\hline $3 \mathrm{Ca}$ & 68 & T3b & 9 & 10.0 & & & & NA & \\
\hline $4 \mathrm{Ca}$ & 62 & T2b & 5 & 5.8 & & & & NA & \\
\hline $5 \mathrm{Ca}$ & 72 & T3a & 6 & 6.5 & & & & & \\
\hline $6 \mathrm{Ca}$ & 65 & T2b & 8 & 7.9 & & & & & \\
\hline $7 \mathrm{Ca}$ & 72 & T3b & 6 & 22.1 & & & & & \\
\hline $8 \mathrm{Ca}$ & 65 & T3b & 7 & 9.3 & & & & & \\
\hline $9 \mathrm{Ca}$ & 66 & T3a & 5 & 7.9 & & & & & \\
\hline $10 \mathrm{Ca}$ & 66 & T2b & 5 & 4.2 & & & & & \\
\hline $11 \mathrm{Ca}$ & 63 & $T 2 b$ & 6 & 10.2 & & & & & \\
\hline $12 \mathrm{Ca}$ & 54 & T3a & 7 & 10.4 & & & & & \\
\hline $13 \mathrm{Ca}$ & 75 & T3a & 7 & 11.2 & & & & & \\
\hline $14 \mathrm{Ca}$ & 71 & T3b & 7 & 17.0 & & & & & \\
\hline $15 \mathrm{Ca}$ & 62 & $T 2 a$ & 6 & 6.7 & & & & NA & \\
\hline $16 \mathrm{Ca}$ & 67 & T3a & 6 & 12.0 & & & & & \\
\hline $17 \mathrm{Ca}$ & 62 & T3 & 6 & 11.8 & & & & & \\
\hline $18 \mathrm{Ca}$ & 55 & T3b & 7 & 9.0 & & & & NA & \\
\hline $19 \mathrm{Ca}$ & 75 & T4 & 7 & 2.1 & & & & & \\
\hline $20 \mathrm{Ca}$ & 75 & T3b & 7 & 5.7 & & & & & \\
\hline $21 \mathrm{Ca}$ & 68 & T3a & 6 & 8.0 & & & & & \\
\hline $22 \mathrm{Ca}$ & 75 & T3b & 9 & 16.0 & & & & & \\
\hline $23 \mathrm{Ca}$ & 69 & T3a & 6 & 15.0 & & & & & \\
\hline $24 \mathrm{Ca}$ & 62 & T3a & 5 & 7.0 & & & & & \\
\hline $25 \mathrm{Ca}$ & 67 & T3a & 7 & 11.0 & & & & & \\
\hline $26 \mathrm{Ca}$ & 64 & T3a & 6 & 7.5 & & & & & \\
\hline $27 \mathrm{Ca}$ & 71 & T2b & 5 & 11.2 & & & & & \\
\hline $28 \mathrm{Ca}$ & 58 & T2b & 3 & 38.0 & & & & & \\
\hline $29 \mathrm{Ca}$ & 65 & T2a & 7 & 18.6 & & & & & \\
\hline $30 \mathrm{Ca}$ & 72 & T4 & 8 & 62.0 & & & & NA & \\
\hline $31 \mathrm{Ca}$ & 70 & T2b & 6 & 9.0 & & NA & & & \\
\hline $32 \mathrm{Ca}$ & 56 & T3a & 2 & 6.8 & & & & & \\
\hline $33 \mathrm{Ca}$ & 71 & $T 2 b$ & 6 & 11.7 & & & & & \\
\hline $34 \mathrm{Ca}$ & 75 & T1a & 2 & 4.8 & & & & & \\
\hline $35 \mathrm{Ca}$ & 72 & T2b & 5 & 14.2 & & & & & \\
\hline $36 \mathrm{Ca}$ & 72 & T2b & 8 & 50.0 & & & & & \\
\hline $37 \mathrm{Ca}$ & 73 & T1a & 3 & 5.5 & & & & & \\
\hline $38 \mathrm{Ca}$ & 71 & T2a & 2 & 1.8 & & & & & \\
\hline 39Ca & 78 & T1a & 4 & 25.0 & & & & & \\
\hline $40 \mathrm{Ca}$ & 66 & T1a & 8 & 3.9 & & & & & \\
\hline $41 \mathrm{Ca}$ & 82 & T2a & 5 & 2.2 & & & & NA & \\
\hline $42 \mathrm{Ca}$ & 65 & T2a & 2 & 2.4 & & & & NA & \\
\hline
\end{tabular}

Benign Prostatic Hyperplasia

\begin{tabular}{|c|c|c|c|l|l|l|l|l|}
\hline No & Age & PSA & CI & VEGF & FGF2 & TGFB1 & EGF & IGF1 \\
\hline $1 \mathrm{H}$ & 61 & 1.9 & YES & & & & & \\
\hline $2 \mathrm{H}$ & 76 & 2.7 & YES & & & & & \\
\hline $3 \mathrm{H}$ & 70 & 1.8 & YES & & & & NA & \\
\hline $4 \mathrm{H}$ & 69 & 4.3 & NO & NA & & & & \\
\hline $5 \mathrm{H}$ & 74 & 7.4 & NO & & & & & \\
\hline $6 \mathrm{H}$ & 84 & 4.5 & YES & & & & NA & \\
\hline $7 \mathrm{H}$ & 64 & 2.1 & YES & & & & NA & \\
\hline $8 \mathrm{H}$ & 74 & 2.8 & YES & & & & & \\
\hline $9 \mathrm{H}$ & 77 & 0.7 & NO & & NA & NA & NA & NA \\
\hline $10 \mathrm{H}$ & 72 & 5.5 & NO & & & & & \\
\hline $11 \mathrm{H}$ & 86 & 0.9 & NO & & & & & \\
\hline $12 \mathrm{H}$ & 61 & 0.1 & NO & & & & & \\
\hline $13 \mathrm{H}$ & 74 & 0.9 & YES & & & & & \\
\hline $14 \mathrm{H}$ & 77 & 2.4 & YES & & & & NA & \\
\hline $15 \mathrm{H}$ & 74 & 0.3 & YES & & & & & \\
\hline $16 \mathrm{H}$ & 69 & 2.5 & YES & & & & & \\
\hline $17 \mathrm{H}$ & 76 & 1.3 & NO & & & & NA & \\
\hline $18 \mathrm{H}$ & 61 & 2.9 & NO & & & & NA & \\
\hline $19 \mathrm{H}$ & 85 & 1.7 & NO & & & & NA & \\
\hline $20 \mathrm{H}$ & 86 & 1.0 & NO & & & & NA & \\
\hline $21 \mathrm{H}$ & 78 & 2.9 & NO & & & & & \\
\hline $22 \mathrm{H}$ & 71 & 0.7 & NO & & & & & \\
\hline $23 \mathrm{H}$ & 82 & 3.3 & YES & & & & & \\
\hline $24 \mathrm{H}$ & 73 & 1.1 & YES & & & & & \\
\hline $25 \mathrm{H}$ & 69 & 2.4 & NO & & & & & \\
\hline $26 \mathrm{H}$ & 85 & 1.7 & YES & & & & & \\
\hline $27 \mathrm{H}$ & 66 & 1.5 & YES & & & & & \\
\hline $28 \mathrm{H}$ & 73 & 2.9 & NO & & & & NA & \\
\hline $29 \mathrm{H}$ & 76 & 2.4 & NO & & & & NA & \\
\hline $30 \mathrm{H}$ & 61 & 1.9 & NO & & & & NA & \\
\hline $31 \mathrm{H}$ & 62 & 1.8 & YES & & & & & \\
\hline $32 \mathrm{H}$ & 68 & 0.7 & YES & & & & & \\
\hline $33 \mathrm{H}$ & 65 & 1.3 & NO & NA & NA & & NA & NA \\
\hline $34 \mathrm{H}$ & 70 & 2.3 & YES & & & & NA & \\
\hline $35 \mathrm{H}$ & 60 & 1.9 & NO & & & & & \\
\hline $36 \mathrm{H}$ & 64 & 1.4 & NO & & & & NA & \\
\hline $37 \mathrm{H}$ & 74 & 1.8 & NO & & & & NA & \\
\hline $38 \mathrm{H}$ & 79 & 1.0 & NO & & & & & \\
\hline $39 \mathrm{H}$ & 72 & 2.3 & NO & & NA & NA & NA & NA \\
\hline $40 \mathrm{H}$ & 73 & 0.9 & YES & & & & NA & \\
\hline $42 \mathrm{H}$ & 69 & 1.8 & NO & & & & & \\
\hline
\end{tabular}

\section{overexpression}

normal expression

\section{reduced expression}

Figure 2. VEGF, FGF2, TGFB1, EGF and IGF1 mRNA expression analysis in prostate cancer and benign prostatic hyperplasia samples. Gl, Gleason score. $\mathrm{CI}$, chronic inflammation. NA, data not available. Blue denotes mRNA overexpression; red denotes mRNA downregulation; green denotes normal mRNA expression.

Fisher's exact test when indicated by the analysis, was used to examine VEGF, FGF2, TGFB1, EGF and IGF1 expression status with the various clinicopathological parameters after stratification. All statistical analyses were 2-sided and performed with SPSS 11.5 (SPSS, Chicago, IL). Statistical significance was set at the $95 \%$ level (p-value $<0.05$ ).

\section{Results}

This study was conducted in order to determine mRNA transcription levels of VEGF, FGF2, TGFB1, EGF and IGF1 peptide growth factors (GF) using a quantitative real-time RT-PCR method. Representative examples of this analysis are shown in Fig. 1. After amplification, standard curves were constructed, from samples used in a series of consecutive dilutions, for both the gene of interest (GF) and the internal control, a housekeeping gene used to normalize the detected
GF mRNA levels (in this case GAPDH). Then for all samples, excluding those with no amplification plots, or with dissociation curves that show signs of primer-dimer formation or by-products, the expression of both the target and the housekeeping gene were calculated, projecting, with the help of the standard curve, the Ct value of all unknown samples to an mRNA quantity (in this case a relative quantity, since the mRNA copy number for both the GF and GAPDH genes was not determined in the samples used to create the standard curve). Then, the mRNA expression of every sample was normalized by dividing the mRNA value of the GF gene with the GAPDH mRNA value. The normalized values of prostate cancer and benign prostatic hyperplasia samples were divided with the average normalized values of all normal samples. The result of this division provides the relative expression of a $\mathrm{PCa}$ or $\mathrm{BPH}$ sample in relation to normal controls. Two-fold increased (a value $\geq 2$ ) or decreased 
Table III. mRNA expression analysis of peptide growth factors in prostate cancer and benign prostatic hyperplasia.

\begin{tabular}{|c|c|c|c|c|c|}
\hline \multirow[b]{2}{*}{ Growth factor } & \multirow[b]{2}{*}{ Prostatic disease } & \multicolumn{3}{|c|}{ Relative mRNA expression } & \multirow[b]{2}{*}{$\mathrm{p}$-value ${ }^{\mathrm{a}}$} \\
\hline & & $\uparrow(\%)$ & $-(\%)$ & $\downarrow(\%)$ & \\
\hline \multirow{2}{*}{ EGF } & $\mathrm{PCa}(\mathrm{n}=35)$ & $14(40.0)$ & 17 (48.6) & $4(11.4)$ & \multirow{2}{*}{0.008} \\
\hline & $\mathrm{BPH}(\mathrm{n}=23)$ & 1 (4.3) & $16(69.6)$ & $6(26.1)$ & \\
\hline \multirow{2}{*}{ FGF2 } & $\mathrm{PCa}(\mathrm{n}=41)$ & $18(43.9)$ & $16(39.0)$ & $7(17.1)$ & \multirow{2}{*}{0.23} \\
\hline & BPH $(n=39)$ & $10(25.6)$ & $21(53.9)$ & $8(20.5)$ & \\
\hline \multirow{2}{*}{ TGFB1 } & $\mathrm{PCa}(\mathrm{n}=42)$ & $3(7.1)$ & $22(52.4)$ & 17 (40.5) & \multirow{2}{*}{0.002} \\
\hline & BPH $(n=40)$ & $2(5.0)$ & $7(17.5)$ & $31(77.5)$ & \\
\hline \multirow{2}{*}{ VEGF } & $\mathrm{PCa}(\mathrm{n}=42)$ & $13(31.0)$ & $19(45.2)$ & $10(23.8)$ & \multirow{2}{*}{0.003} \\
\hline & $\mathrm{BPH}(\mathrm{n}=40)$ & $5(12.5)$ & $11(27.5)$ & $24(60.0)$ & \\
\hline \multirow{2}{*}{ IGF1 } & $\mathrm{PCa}(\mathrm{n}=42)$ & $10(23.8)$ & $12(28.6)$ & 20 (47.6) & \multirow{2}{*}{0.82} \\
\hline & $\mathrm{BPH}(\mathrm{n}=39)$ & $9(23.1)$ & $9(23.1)$ & $21(53.8)$ & \\
\hline
\end{tabular}

$\uparrow$, overexpression; -, normal expression; $\downarrow$, reduced expression. ${ }^{\mathrm{a}} \chi^{2}$ test $(\mathrm{df}=2)$.

(a value $\leq 0.5$ ) expression was considered GF mRNA overexpression or downregulation, respectively. In order to verify the quantification process, representative examples of all target and control genes were analyzed in agarose gels, in order to verify the correct size of the PCR products (and the absence of dimers).

The results of the above mentioned analysis are schematically depicted in Fig. 2, in order to present the expression pattern of all growth factors studied in each benign and malignant prostatic sample. From these results we deduce that the mRNA levels of the five studied growth factors deviate, in most cases, significantly from the normal pattern. In PCa, VEGF is overexpressed in $31 \%$ of samples, FGF2 in $44 \%$ and EGF in $40 \%$. On the contrary, TGFB1 and IGF1 are downregulated in $41 \%$ and $48 \%$ of samples respectively. In $\mathrm{BPH}$, while EGF and FGF2 mRNA levels are in the majority of samples normal, the same does not apply for VEGF, TGFB1 and IGF1, which have reduced levels of mRNA transcripts in $60 \%, 78 \%$ and $54 \%$ of benign cases, respectively. Additionally, as shown in Table III along with the cumulative results of the mRNA expression analysis, the expression pattern between benign and malignant prostate is different for growth factors VEGF, TGFB1 and EGF ( $\chi^{2}$ test, $p=0.003$, $\mathrm{p}=0.002$ and $\mathrm{p}=0.008$ respectively), suggesting a distinct role for these GFs in prostatic disease. The other two cytokines (IGF1 and FGF2) display a similar expression pattern among $\mathrm{PCa}$ and $\mathrm{BPH}$ specimens, suggesting a common pathway of action in both prostate cancer and benign prostatic hyperplasia.

Analysis of GF transcription levels and the clinicopathological parameters of $\mathrm{PCa}$ specimens revealed interesting associations. Prostate samples that have downregulated FGF2 mRNA levels have higher PSA blood levels than samples that exhibit normal FGF2 expression

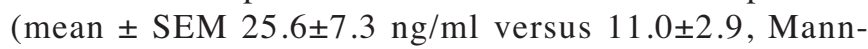

Whitney U test, $\mathrm{p}=0.016$ ). Additionally, EGF overexpression correlates with less severe tumor growth and progression, since samples that have elevated EGF mRNA levels tend to be of low or medium Gleason score $\left(\chi^{2}\right.$ test, $\left.\mathrm{p}=0.035\right)$. Another interesting finding is that EGF levels are higher in prostate cancer patients aged $<70$ years than in older patients $(2.8 \pm 0.6$ vs. 1.8 \pm 0.6 ) (Kruskal-Wallis $\mathrm{H}$ test, $\mathrm{p}=0.056$ ). IGF1 levels also correlate with slower disease progression and differentiation, since prostate tumors, in which IGF1 is overexpressed, have smaller Gleason scores ( $<7$, Fisher's exact test, $\mathrm{p}=0.031)$ and are usually detected in earlier disease stages (T1 or T2 tumors, Fisher's exact test, $\mathrm{p}=0.030$ ) than tumors with normal IGF1 expression. On the contrary, transcript levels of the other two GFs, VEGF and TGFB1, were not correlated with any clinicopathological parameters among prostate cancer specimens.

In BPH, additional associations were discovered. EGF downregulation is observed in patients on average at 8 years older that those with normal EGF mRNA levels (78.0 \pm 2.4 years vs. 69.6 \pm 1.6 , Mann-Whitney $U$ test, $p=0.018)$. IGF1 upregulation is observed in patients on average at 6 years younger that those with normal IGF1 mRNA levels $(66.9 \pm 2.3$ years vs. 73.4 \pm 1.4 , Kruskal-Wallis H test, $\mathrm{p}=0.041)$. Moreover, BPH samples that exhibit reduced TGFB1 mRNA levels have elevated PSA blood levels $(2.5 \pm 0.3 \mathrm{ng} / \mathrm{ml}$ vs. $1.6 \pm 0.4$ ) (Kruskal-Wallis $\mathrm{H}$ test, $\mathrm{p}=0.083$ ). All other associations tested, including those of GFs VEGF and FGF2, were not statistically significant.

Finally, with the Spearman rank correlation, we tested, in a pair-wise manner, the co-expression patterns of the five examined growth factors in normal, benign and malignant prostate. This test examines whether two GFs are upregulated or downregulated together (positive correlation), or whether when one GF is overexpressed the other has reduced expression (negative correlation). These results are displayed in Table IV. In normal prostate (Table IVA) only two molecules are co- 
Table IV. VEGF, FGF2, TGFB1, EGF and IGF1 pair-wise coexpression analysis in normal, benign and malignant prostate.

A. Normal prostate

\begin{tabular}{lcccccc}
\hline & & VEGF & FGF2 & TGFB1 & EGF & IGF1 \\
\hline VEGF & $\begin{array}{c}\text { CC } \\
\text { p-value }\end{array}$ & 1.000 & & & & \\
& & & & & & \\
FGF2 & CC & 0.500 & 1.000 & & & \\
& p-value & 0.667 & & & & \\
TGFB1 & CC & 0.500 & -0.500 & 1.000 & & \\
& p-value & 0.667 & 0.667 & & & \\
EGF & CC & 0.500 & 1.000 & -0.500 & 1.000 & \\
& p-value & 0.667 & $<\mathbf{0 . 0 0 1}$ & 0.667 & & \\
IGF1 & CC & -0.500 & 0.500 & -1.000 & 0.500 & 1.000 \\
& p-value & 0.667 & 0.667 & $<\mathbf{0 . 0 0 1}$ & 0.667 & \\
\hline
\end{tabular}

B. Benign prostatic hyperplasia

\begin{tabular}{lcccccc}
\hline & & VEGF & FGF2 & TGFB1 & EGF & IGF1 \\
\hline VEGF & $\begin{array}{c}\text { CC } \\
\text { p-value }\end{array}$ & 1.000 & & & & \\
& & & & & \\
FGF2 & CC & 0.425 & 1.000 & & & \\
& p-value & $\mathbf{0 . 0 0 8}$ & & & & \\
TGFB1 & CC & 0.445 & 0.647 & 1.000 & & \\
& p-value & $\mathbf{0 . 0 0 5}$ & $<\mathbf{0 . 0 0 1}$ & & & \\
EGF & CC & 0.321 & 0.491 & 0.357 & 1.000 & \\
& p-value & 0.145 & $\mathbf{0 . 0 1 7}$ & 0.094 & & \\
& CC & 0.470 & 0.744 & 0.733 & 0.443 & 1.000 \\
IGF1 & p-value & $\mathbf{0 . 0 0 3}$ & $<\mathbf{0 . 0 0 1}$ & $<\mathbf{0 . 0 0 1}$ & $\mathbf{0 . 0 3 4}$ & \\
& & & & & & \\
\end{tabular}

C. Prostate cancer

\begin{tabular}{lcccccc}
\hline & & VEGF & FGF2 & TGFB1 & EGF & IGF1 \\
\hline VEGF & CC & 1.000 & & & & \\
& p-value & & & & & \\
FGF2 & CC & 0.359 & 1.000 & & & \\
& p-value & $\mathbf{0 . 0 2 1}$ & & & & \\
TGFB1 & CC & 0.412 & 0.793 & 1.000 & & \\
& p-value & $\mathbf{0 . 0 0 7}$ & $<\mathbf{0 . 0 0 1}$ & & & \\
EGF & CC & 0.553 & 0.245 & 0.155 & 1.000 & \\
& p-value & $\mathbf{0 . 0 0 1}$ & 0.163 & 0.373 & & \\
IGF1 & CC & 0.270 & 0.807 & 0.660 & 0.207 & 1.000 \\
& p-value & 0.083 & $<\mathbf{0 . 0 0 1}$ & $<\mathbf{0 . 0 0 1}$ & 0.232 & \\
\hline
\end{tabular}

$\mathrm{CC}$, correlation coefficient. expressed, EGF and FGF2 (Spearman's rho, p<0.001), while two other, TGFB1 and IGF1, are expressed in a reverse manner (Spearman's rho, $\mathrm{p}<0.001$ ). The first correlation (EGF and FGF2) is retained in BPH (Table IVB) (Spearman's rho, $\mathrm{p}=0.017$ ), while the negative correlation between TGFB1 and IGF1 becomes positive (Spearman's rho, $\mathrm{p}<0.001$ ). Additionally, new positive co-expressions appear, that were not present in normal prostate: VEGF is co-expressed with FGF2 (Spearman's rho, $\mathrm{p}=0.008$ ), TGFB1 (Spearman's rho, $\mathrm{p}=0.005$ ) and IGF1 (Spearman's rho, $\mathrm{p}=0.003$ ); FGF2 is co-expressed with TGFB1 (Spearman's rho, $\mathrm{p}<0.001$ ) and IGF1 (Spearman's rho, $\mathrm{p}<0.001$ ); and EGF is co-expressed with IGF1 (Spearman's rho, $\mathrm{p}=0.034$ ). In prostate cancer (Table IVC), when compared with normal prostate, the co-expression between EGF and FGF2 is lost, while the negative correlation between TGFB1 and IGF1 becomes positive (Spearman's rho, $\mathrm{p}<0.001$ ). Moreover, new positive co-expressions are formed: VEGF is co-expressed with FGF2 (Spearman's rho, p=0.021), TGFB1 (Spearman's rho, $\mathrm{p}=0.007$ ) and EGF (Spearman's rho, $\mathrm{p}=0.001$ ); and FGF2 is co-expressed with TGFB1 (Spearman's rho, $\mathrm{p}<0.001$ ) and IGF1 (Spearman's rho, $\mathrm{p}<0.001)$. When compared with $\mathrm{BPH}$, the co-expression patterns of growth factors also differ in PCa. VEGF and EGF co-expression is not present in $\mathrm{BPH}$, while PCa loses three co-expressions present in BPH: VEGF and IGF1; FGF2 and EGF; EGF and IGF1. From the above results we deduce that the coexpression patterns of the five studied growth factors differ significantly among normal, benign and malignant prostate, suggesting that the role these growth factors play in the three conditions of the prostate gland is significantly different.

\section{Discussion}

The prostate gland provides the semen with vitamins and other nutrients thus maintaining its vitality during the journey up the female reproductive system. Diseases of the prostate gland, affect millions of people every year, decreasing their quality of life, while in the case of prostate cancer it can prove lethal if not diagnosed in early stages. Identification of genetic and molecular events that could help in the early detection of benign prostatic hyperplasia and prostate cancer, or could be useful as therapeutic targets, is of top priority in research in this scientific field.

In this study we determined the mRNA levels of peptide growth factors VEGF, FGF2, TGFB1, EGF and IGF1 in normal, benign and malignant prostate and correlated the results with patients' clinicopathological data, in an attempt to find associations that could be potentially useful in the clinical practice. The growth factors selected are the most common representatives of five very important growth factor families that are involved in nearly all intracellular processes, and therefore influence cells significantly $(9,10)$.

The use of a quantitative real-time PCR method also provides several advantages over the semi-quantitative RTPCR process. Its results are more reliable, since the quantification is not performed during the final PCR cycles, where several inhibitory factors (primer-dimers, $\mathrm{Mg}^{+2}$ and dNTPs depletion, polymerase enzyme loss of activity) can alter the formation of the PCR product, but during the initial quantification cycles, where such limitations do not apply. 
Additionally, in real-time QPCR, data collection is performed with a laser, that is far more sensitive than ethidium bromide or $\mathrm{Ag}^{+}$, which are used by the classic PCR products' detection techniques. It is also time-saving, since the overall process takes only a little longer than a standard PCR, while the semi-quantitative PCR requires the analysis of the PCR products in an agarose or polyacrylamide gel, which is timeconsuming. Data quantification is also performed automatically in real-time PCR, with the installed software, and does not require image analysis software, which are expensive and the majority of the work is done manually anyway, that are necessary with the old quantification techniques. Of course there are a few drawbacks. Real-time PCR is more expensive (a side-effect of the increased system sensitivity), since it requires optimized reaction mixes. The analyses are also conducted in triplicates by default, which increases the cost significantly (more PCR master mixes and additional reverse transcription kits, which means that tissue samples, which are usually valuable assets of a laboratory, are depleted more frequently). Additional drawbacks are higher maintenance costs, due to the high-tech instruments, such as the laser, and the fact that during the quantification process the PCR products are not visualized, in order to confirm whether the amplification plots are the correct ones, and not produced from primer-dimers or other by-products. This requires, at least during the initial experiments, the verification of the results obtained from the real-time PCR thermal cycler with gel analysis.

VEGF, as one of the most important promoters of angiogenesis, is overexpressed in a variety of human malignancies (50), contributing significantly to tumor growth and metastasis. Our results, in which we detected overexpression of VEGF in prostate cancer, are in accordance with previous studies conducted in prostate cancer cell lines and primary tumors $(53,54)$. The VEGF mRNA levels do not correlate with any clinicopathological variables, which suggests that VEGF plays an important role during both tumor initiation and progression. On the contrary, VEGF was down-regulated in the majority of our BPH samples. The literature is conflicting regarding this matter, since VEGF has been detected (53) or not (64) in BPH cells. Since FGF2 levels are normal or upregulated in our series of BPH samples, possibly FGF2 is the main angiogenic factor in $\mathrm{BPH}$, and therefore VEGF expression is not necessary in order to induce angiogenesis in prostatic hyperplasia.

TGFB is usually expressed at low levels in the normal prostate gland (39), while its production is increased mainly after androgen depletion (65), a process that is reversible upon androgen administration (66). This increase is also followed by an increase in the levels of TGFBR 1 and TGFBR2 (67). TGFB is usually upregulated in prostate cancer. Its increasing levels correlate with cancer progression (43). However, in this series of prostate tumors, TGFB1 was downregulated. This can be attributed to the fact that all our cases were androgen-dependent prostate neoplasias, which means that they are still under androgen regulation preventing the elevation of TGFB levels. TGFB1 levels were also downregulated in BPH samples. Previous studies have shown that TGFB2 mRNA levels increase in prostatic hyperplasia (23). Therefore, the main molecule of the TGFB family that is involved in the pathogenesis of this disease is the TGFB2, indicating that expression of the other two TGFB isoforms is probably not necessary for disease development and progression.

FGF2 is a growth factor that is synthesized by many prostate cell types besides fibroblasts, such as epithelial cells, macrophages and endothelial cells $(19,68)$. Its levels usually increase in prostate cancer (24), an observation which correlates with our findings. FGF2 has the ability to induce malignant epithelial cells to proliferate independently of stromal control (24), a finding which correlates with disease progression. FGF2 also plays an important role in angiogenesis, by inducing VEGF (50), which was verified by our results, since both factors were overexpressed in $\mathrm{PCa}$ and have positive co-expression. Previous studies have shown FGF2 overexpression in BPH $(21,23)$. However, in our study samples, FGF2 levels were in most BPH samples normal, although $25 \%$ of hyperplasias overexpressed FGF2, indicating that FGF2 is the main angiogenic factor in $\mathrm{BPH}$.

EGF is the ligand of the EGFR, one of the most wellstudied oncogenes. EGF expression is under androgen control in normal prostate, while mRNA overexpression has been detected in the epithelium of PCa specimens $(14,15)$. EGF is upregulated in our series of PCa samples, a finding which correlates with tumors with lower Gleason score. This could mean that EGF plays a significant role during the early stages of cancer development, while in later stages its role is not so prominent. EGF levels are normal in BPH. The fact that patients with lower EGF mRNA levels are on average 8 years older than patients with normal EGF levels, indicates that EGF downregulation delays significantly the development of $\mathrm{BPH}$.

IGF1 levels are downregulated in both PCa and BPH. However, about $25 \%$ of samples in both diseases overexpress IGF1. This overexpression is correlated with lower Gleason score and tumor stage for PCa samples, which could mean, as in the case of EGF, that IGF1 plays an important role during the early stages of carcinogenesis; and with decreased age in BPH patients, in antithesis to the role EGF plays in prostatic hyperplasia, that IGF1 elevated mRNA levels contribute to earlier BPH development.

The growth factors tested in our study also exhibit different expression and co-expression patterns among normal, benign and malignant prostate. These discrepancies have been observed in various other human malignancies and precancerous lesions (69), showing that benign and malignant prostatic cells use the network of autocrine and paracrine peptide growth factors in a different manner, in order to achieve their goals, hypertrophy in the case of $\mathrm{BPH}$ and immortality in the case of PCa. This study has identified some of the interactions among peptide growth factors, implicating them in the development of both $\mathrm{PCa}$ and $\mathrm{BPH}$, and has pointed out associations with patients' clinical and histological parameters, which could lead to early detection and potential therapy for prostatic disease.

\section{Acknowledgements}

N.S. was partially supported by the pre-doctoral scholarship of the 'Maria Michael Manassaki' foundation. 


\section{References}

1. Jemal A, Murray T, Ward E, Samuels A, Tiwari RC, Ghafoor A, Feuer EJ and Thun MJ: Cancer statistics, 2005. CA Cancer J Clin 55: 10-30, 2005

2. Nelson WG, De Marzo AM and Isaacs WB: Prostate cancer. N Engl J Med 349: 366-381, 2003.

3. Stanford JL, Just JJ, Gibbs M, Wicklund KG, Neal CL, Blumenstein BA and Ostrander EA: Polymorphic repeats in the androgen receptor gene: molecular markers of prostate cancer risk. Cancer Res 57: 1194-1198, 1997.

4. Schulz WA, Burchardt M and Cronauer MV: Molecular biology of prostate cancer. Mol Hum Reprod 9: 437-448, 2003.

5. Foster CS: Pathology of benign prostatic hyperplasia. Prostate 9 (Suppl): 4-14, 2000.

6. Di Silverio F, Gentile V, De Matteis A, Mariotti G, Giuseppe V, Luigi PA and Sciarra A: Distribution of inflammation, premalignant lesions, incidental carcinoma in histologically confirmed benign prostatic hyperplasia: a retrospective analysis. Eur Urol 43: 164-175, 2003 .

7. Pavelic J, Zeljko Z and Bosnar MH: Molecular genetic aspects of prostate transition zone lesions. Urology 62: 607-613, 2003.

8. Lee KL and Peehl DM: Molecular and cellular pathogenesis of benign prostatic hyperplasia. J Urol 172: 1784-1791, 2004.

9. Steiner MS: Review of peptide growth factors in benign prostatic hyperplasia and urological malignancy. J Urol 153: 1085-1096, 1995.

10. Hellawell GO and Brewster SF: Growth factors and their receptors in prostate cancer. BJU Int 89: 230-240, 2002.

11. Ullrich A, Coussens L, Hayflick JS, et al: Human epidermal growth factor receptor cDNA sequence and aberrant expression of the amplified gene in A431 epidermoid carcinoma cells. Nature 309: 418-425, 1984.

12. Massague J: Transforming growth factor-alpha. A model for membrane-anchored growth factors. J Biol Chem 265: 21393-21396, 1990.

13. Gregory H, Willshire IR, Kavanagh JP, Blacklock NJ, Chowdury S and Richards RC: Urogastrone-epidermal growth factor concentrations in prostatic fluid of normal individuals and patients with benign prostatic hypertrophy. Clin Sci (Lond) 70: 359-363, 1986.

14. Yang Y, Chisholm GD and Habib FK: Epidermal growth factor and transforming growth factor alpha concentrations in $\mathrm{BPH}$ and cancer of the prostate: their relationships with tissue androgen levels. Br J Cancer 67: 152-155, 1993.

15. Glynne-Jones E, Goddard L and Harper ME: Comparative analysis of mRNA and protein expression for epidermal growth factor receptor and ligands relative to the proliferative index in human prostate tissue. Hum Pathol 27: 688-694, 1996.

16. Bikfalvi A, Klein S, Pintucci G and Rifkin DB: Biological roles of fibroblast growth factor-2. Endocr Rev 18: 26-45, 1997.

17. Weidner N, Carroll PR, Flax J, Blumenfeld W and Folkman J: Tumor angiogenesis correlates with metastasis in invasive prostate carcinoma. Am J Pathol 143: 401-409, 1993.

18. Pienta KJ, Isaacs WB, Vindivich D and Coffey DS: The effects of basic fibroblast growth factor and suramin on cell motility and growth of rat prostate cancer cells. J Urol 145: 199-202, 1991 .

19. Story MT, Livingston B, Baeten L, Swartz SJ, Jacobs SC, Begun FP and Lawson RK: Cultured human prostate-derived fibroblasts produce a factor that stimulates their growth with properties indistinguishable from basic fibroblast growth factor. Prostate 15: 355-365, 1989.

20. Nakamoto T, Chang CS, Li AK and Chodak GW: Basic fibroblast growth factor in human prostate cancer cells. Cancer Res 52: 571-577, 1992.

21. Ropiquet F, Giri D, Lamb DJ and Ittmann M: FGF7 and FGF2 are increased in benign prostatic hyperplasia and are associated with increased proliferation. J Urol 162: 595-599, 1999.

22. Mydlo JH, Bulbul MA, Richon VM, Heston WD and Fair WR: Heparin-binding growth factor isolated from human prostatic extracts. Prostate 12: 343-355, 1988.

23. Mori H, Maki M, Oishi K, Jaye M, Igarashi K, Yoshida O and Hatanaka M: Increased expression of genes for basic fibroblast growth factor and transforming growth factor type beta 2 in human benign prostatic hyperplasia. Prostate 16: 71-80, 1990.

24. Cronauer MV, Hittmair A, Eder IE, Hobisch A, Culig Z, Ramoner R, Zhang J, Bartsch G, Reissigl A, Radmayr C, Thurnher $\mathrm{M}$ and Klocker $\mathrm{H}$ : Basic fibroblast growth factor levels in cancer cells and in sera of patients suffering from proliferative disorders of the prostate. Prostate 31: 223-233, 1997.
25. Derynck R, Jarrett JA, Chen EY, Eaton DH, Bell JR, Assoian RK, Roberts AB, Sporn MB and Goeddel DV: Human transforming growth factor-beta complementary DNA sequence and expression in normal and transformed cells. Nature 316: 701-705, 1985.

26. Matuo Y, McKeehan WL, Yan GC, Nikolaropoulos S, Adams PS, Fukabori Y, Yamanaka $\mathrm{H}$ and Gaudreau J: Potential role of HBGF (FGF) and TGF-beta on prostate growth. Adv Exp Med Biol 324: 107-114, 1992.

27. Pelton RW, Saxena B, Jones M, Moses HL and Gold LI: Immunohistochemical localization of TGF beta 1 , TGF beta 2 , and TGF beta 3 in the mouse embryo: expression patterns suggest multiple roles during embryonic development. J Cell Biol 115: 1091-1105, 1991.

28. Moses HL, Yang EY and Pietenpol JA: TGF-beta stimulation and inhibition of cell proliferation: new mechanistic insights. Cell 63: 245-247, 1990 .

29. Nilsen-Hamilton M: Transforming growth factor-beta and its actions on cellular growth and differentiation. Curr Top Dev Biol 24: 95-136, 1990.

30. Lyons RM, Keski-Oja J and Moses HL: Proteolytic activation of latent transforming growth factor-beta from fibroblastconditioned medium. J Cell Biol 106: 1659-1665, 1988.

31. Roberts AB, Sporn MB, Assoian RK, et al: Transforming growth factor type beta: rapid induction of fibrosis and angiogenesis in vivo and stimulation of collagen formation in vitro. Proc Natl Acad Sci USA 83: 4167-4171, 1986.

32. Edwards DR, Murphy G, Reynolds JJ, Whitham SE, Docherty AJ, Angel $\mathrm{P}$ and Heath JK: Transforming growth factor beta modulates the expression of collagenase and metalloproteinase inhibitor. EMBO J 6: 1899-1904, 1987.

33. Massague J: The transforming growth factor-beta family. Annu Rev Cell Biol 6: 597-641, 1990.

34. Torre-Amione G, Beauchamp RD, Koeppen H, Park BH, Schreiber H, Moses HL and Rowley DA: A highly immunogenic tumor transfected with a murine transforming growth factor type beta 1 cDNA escapes immune surveillance. Proc Natl Acad Sci USA 87: 1486-1490, 1990.

35. Fontana A, Constam DB, Frei K, Malipiero U and Pfister HW: Modulation of the immune response by transforming growth factor beta. Int Arch Allergy Immunol 99: 1-7, 1992.

36. Wrana JL, Attisano L, Wieser R, Ventura F and Massague J. Mechanism of activation of the TGF-beta receptor. Nature 370 341-347, 1994

37. Barrack ER: TGF beta in prostate cancer: a growth inhibitor that can enhance tumorigenicity. Prostate 31: 61-70, 1997.

38. Martikainen P, Kyprianou N and Isaacs JT: Effect of transforming growth factor-beta 1 on proliferation and death of rat prostatic cells. Endocrinology 127: 2963-2968, 1990.

39. Ilio KY, Sensibar JA and Lee C: Effect of TGF-beta 1, TGFalpha, and EGF on cell proliferation and cell death in rat ventral prostatic epithelial cells in culture. J Androl 16: 482-490, 1995.

40. Cunha GR, Alarid ET, Turner T, Donjacour AA, Boutin EL and Foster BA: Normal and abnormal development of the male urogenital tract. Role of androgens, mesenchymal-epithelial interactions, and growth factors. J Androl 13: 465-475, 1992.

41. Sutkowski DM, Fong CJ, Sensibar JA, Rademaker AW, Sherwood ER, Kozlowski JM and Lee C: Interaction of epidermal growth factor and transforming growth factor beta in human prostatic epithelial cells in culture. Prostate 21: 133-143, 1992.

42. Thompson TC, Truong LD, Timme TL, Kadmon D, McCune BK, Flanders KC, Scardino PT and Park SH: Transforming growth factor beta 1 as a biomarker for prostate cancer. J Cell Biochem 16H (Suppl): 54-61, 1992.

43. Truong LD, Kadmon D, McCune BK, Flanders KC, Scardino PT and Thompson TC: Association of transforming growth factorbeta 1 with prostate cancer: an immunohistochemical study. Hum Pathol 24: 4-9, 1993.

44. Perry KT, Anthony CT and Steiner MS: Immunohistochemical localization of TGF beta 1 , TGF beta 2 , and TGF beta 3 in normal and malignant human prostate. Prostate 33: 133-140, 1997.

45. Yang EY and Moses HL: Transforming growth factor beta 1induced changes in cell migration, proliferation, and angiogenesis in the chicken chorioallantoic membrane. J Cell Biol 111: 731-741, 1990.

46. Letterio JJ and Roberts AB: Regulation of immune responses by TGF-beta. Annu Rev Immunol 16: 137-161, 1998.

47. Steiner MS and Barrack ER: Transforming growth factor-beta 1 overproduction in prostate cancer: effects on growth in vivo and in vitro. Mol Endocrinol 6: 15-25, 1992. 
48. Ignotz RA and Massague J: Transforming growth factor-beta stimulates the expression of fibronectin and collagen and their incorporation into the extracellular matrix. J Biol Chem 261: 4337-4345, 1986.

49. Welch DR, Fabra A and Nakajima M: Transforming growth factor beta stimulates mammary adenocarcinoma cell invasion and metastatic potential. Proc Natl Acad Sci USA 87: 7678-7682, 1990.

50. Ferrara N: Vascular endothelial growth factor: basic science and clinical progress. Endocr Rev 25: 581-611, 2004.

51. Mukhopadhyay D, Tsiokas L, Zhou XM, Foster D, Brugge JS and Sukhatme VP: Hypoxic induction of human vascular endothelial growth factor expression through c-Src activation. Nature 375: 577-581, 1995.

52. Bates DO and Curry FE: Vascular endothelial growth factor increases hydraulic conductivity of isolated perfused microvessels. Am J Physiol 271: H2520-H2528, 1996.

53. Jackson MW, Bentel JM and Tilley WD: Vascular endothelial growth factor (VEGF) expression in prostate cancer and benign prostatic hyperplasia. J Urol 157: 2323-2328, 1997.

54. Campbell CL, Savarese DM, Quesenberry PJ and Savarese TM: Expression of multiple angiogenic cytokines in cultured normal human prostate epithelial cells: predominance of vascular endothelial growth factor. Int J Cancer 80: 868-874, 1999.

55. Stewart RJ, Panigrahy D, Flynn E and Folkman J: Vascular endothelial growth factor expression and tumor angiogenesis are regulated by androgens in hormone responsive human prostate carcinoma: evidence for androgen dependent destabilization of vascular endothelial growth factor transcripts. J Urol 165 : 688-693, 2001.

56. Aaronson SA: Growth factors and cancer. Science 254: 1146-1153, 1991.

57. Iwamura M, Sluss PM, Casamento JB and Cockett AT: Insulinlike growth factor I: action and receptor characterization in human prostate cancer cell lines. Prostate 22: 243-252, 1993.

58. Nakae J, Kido Y and Accili D: Distinct and overlapping functions of insulin and IGF-I receptors. Endocr Rev 22:818-835, 2001.

59. Khandwala HM, McCutcheon IE, Flyvbjerg A and Friend KE: The effects of insulin-like growth factors on tumorigenesis and neoplastic growth. Endocr Rev 21: 215-244, 2000
60. Wang YZ and Wong YC: Sex hormone-induced prostatic carcinogenesis in the noble rat: the role of insulin-like growth factor-I (IGF-I) and vascular endothelial growth factor (VEGF) in the development of prostate cancer. Prostate 35: 165-177, 1998.

61. Chan JM, Stampfer MJ, Giovannucci E, Gann PH, Ma J, Wilkinson P, Hennekens CH and Pollak M: Plasma insulin-like growth factor-I and prostate cancer risk: a prospective study. Science 279: 563-566, 1998.

62. Wolk A, Mantzoros CS, Andersson SO, Bergstrom R, Signorello LB, Lagiou P, Adami HO and Trichopoulos D: Insulin-like growth factor 1 and prostate cancer risk: a populationbased, case-control study. J Natl Cancer Inst 90: 911-915, 1998.

63. Mantzoros CS, Tzonou A, Signorello LB, Stampfer M Trichopoulos D and Adami HO: Insulin-like growth factor 1 in relation to prostate cancer and benign prostatic hyperplasia. Br J Cancer 76: 1115-1118, 1997.

64. Ferrer FA, Miller LJ, Andrawis RI, Kurtzman SH, Albertsen PC, Laudone VP and Kreutzer DL: Vascular endothelial growth factor (VEGF) expression in human prostate cancer: in situ and in vitro expression of VEGF by human prostate cancer cells. J Urol 157: 2329-2333, 1997.

65. Kyprianou $\mathrm{N}$ and Isaacs JT: Expression of transforming growth factor-beta in the rat ventral prostate during castration-induced programmed cell death. Mol Endocrinol 3: 1515-1522, 1989.

66. Kyprianou N, English HF and Isaacs JT: Programmed cell death during regression of PC-82 human prostate cancer following androgen ablation. Cancer Res 50: 3748-3753, 1990.

67. Landstrom M, Eklov S, Colosetti P, Nilsson S, Damber JE, Bergh $\mathrm{A}$ and Funa $\mathrm{K}$ : Estrogen induces apoptosis in a rat prostatic adenocarcinoma: association with an increased expression of TGF-beta 1 and its type-I and type-II receptors. Int J Cancer 67: 573-579, 1996.

68. Schweigerer L, Neufeld G, Friedman J, Abraham JA, Fiddes JC and Gospodarowicz D: Capillary endothelial cells express basic fibroblast growth factor, a mitogen that promotes their own growth. Nature 325: 257-259, 1987.

69. Soufla G, Sifakis S, Baritaki S, Zafiropoulos A, Koumantakis E and Spandidos DA: VEGF, FGF2, TGFB1 and TGFBR1 mRNA expression levels correlate with the malignant transformation of the uterine cervix. Cancer Lett 221: 105-118, 2005. 